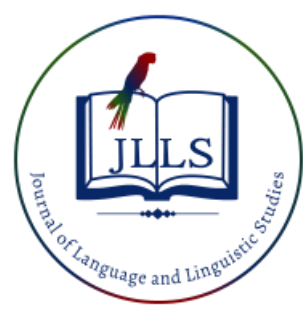

Available online at www.jlls.org

JOURNAL OF LANGUAGE AND LINGUISTIC STUDIES

ISSN: 1305-578X

Journal of Language and Linguistic Studies, 17(1), 529-541; 2021

\title{
Education during Covid19: Islamic perspectives on ethics for new media users
}

\author{
for teachers and students
}

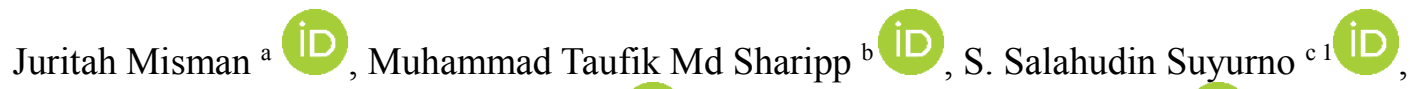 \\ Nik Narimah Nik Abdullah ${ }^{\text {(iD }}$, Chairozila Mohd. Shamsudin ${ }^{\text {e iD }}$ \\ a Academy of Language Studies, UiTM Cawangan Melaka, Malaysia \\ ${ }^{b}$ Academy of Contemporary Islamic Studies, UiTM Cawangan Melaka, Malaysia \\ ${ }^{c}$ Academy of Contemporary Islamic Studies (ACIS), UiTM Cawangan Melaka, Malaysia \\ ${ }^{d}$ Arts and Design Faculty, UiTM Cawangan Melaka, Malaysia \\ ${ }^{e}$ Pusat Citra UKM, Malaysia
}

\section{APA Citation:}

Misman, J., Sharipp, M.T.M., Suyurno, S.S., Abdullah, N.N.N., \& Shamsudin, C.M. (2021). Education during Covid19: Islamic perspectives on ethics for new media users for teachers and students. Journal of Language and Linguistic Studies, 17(1), 529-541. Doi: 10.52462/jlls.35

Submission Date: 09/01/2021

Acceptance Date: 13/03/2021

\begin{abstract}
With the current situation of Covid19 outbreaks and the execution of lockdowns and social restrictions and distancing, people are turning to the use of smart technologies to communicate and perform daily activities. In fact, current education scenario during Covid19 has increased the need to use new media in the teaching and learning processes. In order to be a good user of the new media technology, Muslims must advocate to the principles of upholding knowledge and guidance from truthful sources of knowledge such as the Quran and Hadith to avoid becoming deviant users of the new media. The main objective of this paper is to present the Islamic perspectives in terms of the ethics of using the new media in education during covid19. This concept paper analyses data extracted from referencing secondary sources such as academic journal articles, scholarly books and online newspaper articles to understand new media and the current online distance learning situations taking place during the Covid19 phenomena. These guidelines would contribute towards aiding teachers and students to have an increase of knowledge and awareness towards the usage of new media as tools during the distance learning transformation while facing the hurdles of life-long learning situations during Covid19.
\end{abstract}

Keywords: new media; Islamic perspectives; ethics; education; Covid19

\section{Introduction}

Due to the current situations of Covid19 outbreaks and the increase in the number of Covid19 cases, nations around the world have implemented various prevention measures to manage and stop human to human spread of the deadly and contagious virus. In the early months of 2020, as a health measure to curb the infection of the dangerous virus, many nations, including Malaysia have given directives that learning institutions including schools and higher learning institutions be closed (Sipalan, 2020). Accordingly, people have to stay at home, and learning and teaching processes was forced to continue online. According to the teaching of Prophet Muhammad, the quest for knowledge

\footnotetext{
${ }^{1}$ Corresponding author.

E-mail address: ssalahud@uitm.edu.my
} 
is the duty of each Muslim, male and female (Yahe Pallavicini, 2016). In pursuing online learning sessions, new media such as smartphone, social media, computer, virtual media tool, single media, and online game are preferred instruments used during these challenging Covid19 times.

Basically, in the modern world, the surge in the use of new media and digital technology has transformed almost everything on how we live our life. These transformations affected numerous facets such as information, communication, teaching and learning, entertainment, politics, management, security, traveling, economics, finance and others (Juritah et al., 2018). Smart technology developments have changed the way people think, work, learn, communicate, entertain, play, do business, pay bill, and do other chores. Significantly, there are various challenging issues due to the increasing use of new media in the social and education environment (Jamiah, 2016).

\section{Literature Review}

\subsection{New Media}

New media is a much-used tool by people all around the world during the Covid19 health crisis as many nations execute social distancing and lockdowns to curb the spread of the coronavirus from spreading from human to human. At present, people use social media platforms such as Instagram, Blogs, Facebook, Whats App, We Chat, Twitter, Telegram, Tik-Tok and YouTube platforms for various purposes such as for teaching and learning, communicating, sharing, and anything related to online media contexts. A study by Jamiah et al. (2016) reported that the $\mathrm{Z}$ generation in Malaysia highly used the social media platforms such as the Instagram, followed by Facebook and Twitter and We Chat; whereas, the teenagers used platforms such as the Whats App, Blogs, YouTube and Telegram at a moderate level.

Moreover, our young generation today are very keen towards using the interactive virtual network which provides various interesting and helpful tools such as capturing camera images, recording, videos, audio, graphic, AR, emoji and others when they communicate and do networking with others. No matter whether they are far or near, with the use of new media, sharing meaning and understanding becomes faster, and when the sharing of meaning and understanding can be easily translated, communication becomes more successful (Zulkefli and S.Salahudin, 2012). In brief, the young generation use these new media tools for a variety of purposes, be it for networking, or interaction activities.

\subsection{New Media in Education During Covid19}

During the Covid19 situations, in facing the challenges of the online distance learning situations, the process of education which utilise new media and digital platforms should not separate education related to divinity, morality, ethics in line with the development of today's world (Zetty Nurzuliana and Ab.Halim, 2015). Digital media technology can be used for education purposes and to transmit knowledge in line with Islam and its religious teachings. In fact, Islamic teachings also encourage Muslims to pursue knowledge and innovation in science and technology to improve their life activities, and that consequently the main goals of these deeds should be aimed towards worshipping Allah. Significantly in Islam, individuals should have the passion to pursue life-long learning to become knowledgeable ummah (society).

In addition, Aziz Rehman et al. (2012) recommended the use of media technology such as using relevant television channels such as television programmes, game shows, plays, talks and cartoons, websites, ICT such as multimedia and video presentations, to be used in the teaching and learning process and also to spread the message of Islam and good human values to the people. For example, 
during the Covid19 situations, people from different parts of the world can access Islamic information and other teachings from well-known Islamic scholars from around the world such as the Preacher Mufti Menk, Ustaz Abdul Somad, Ustaz Datuk Dr. Zulkifli Mohamad Al-Bakri or Professor Dr. Muhaya through live or recorded talks and even participating in online preaching sessions by posing questions and providing online feedback. While being quarantined at home or while working from home, people could spend more of their private time whether alone or together with their family members to access these religious online learning and communication platforms to obtain various knowledge and skills. More importantly, during the Covid19 stay-at-home situations, preachers could be active online and give preaching, teaching, provide consultations, share videos and so on through various online media platforms such as through live sessions through Facebook, Instagram, Google Meet, Zoom and others to disseminate knowledge and information to the mass. Other learning sessions include Quran recitals and prayers which are shared online to spread the message of Islam to people.

Essentially, the users of new media in education are mostly the young ones. Today, contemporary education is more versatile. This means that education can occur online and educators and students can engage in flexible learning programmes, virtual classrooms, and collaborate with virtual learning partners from various fields and professions. As a result, education can cater to everyone's needs regardless of age groups or professions. With regards to virtual classrooms, Islam advocates that there is the concept of science integration which is based on the integration of faith and knowledge, body and spirit, mind and heart, intellect and revelation. Therefore, the emphasis on physical, emotional, spiritual, and intellectual elements should be prioritized in education especially when using the new media (Juritah et al., 2018).

Apart from the benefits of using new media, there are also the negative influences of the new media to students. Jamiah et al. (2016) claimed that young student respondents used the social media at long interval duration every day, up to 11.6 hours to 24 hours. The young generation prefer to socialise and communicate using Instagram platforms even spending time to upload daily activities in video and picture forms. They also do online shopping through the Instagram platforms. One of the risk of using the new media platforms is that there are instances where students spend long hours on the internet and social media platforms each day. They access the new media for various reasons such as to access information, chat, discuss lessons, build networking, post and share their daily activities, do online shopping, entertainment and make instantaneous communication. In brief, social media platforms have positive and negative consequences.

\subsection{Ethics in Using New Media in Education}

Ethics are codes and values that guide individuals to be able to discern what is right and wrong so that society uses new media tools positively with good moral principles especially in the education processes during Covid19. Past research conducted on online learning also concluded on the significance of ethics to guide users of online learning. Lengel (2004) presented Code of Ethics listed by Association of Computing Society which comprised of aspects such as contributing to society and human well-being, avoiding harm, honesty, fair, honour property rights, give proper credit and respect other's privacy. Toprak et al. (2010) in their study on ethics in e-learning stated that approximately $67 \%$ of student respondents and 39\% lecturers agreed that to decrease problems pertaining to bandwidth and internet access during e-learning, only essential multimedia aspects such as graphics, audio, videos accompanied by text should be used in the teaching and learning process.

Another study done by Busikova and Melicherikova (2013) on the disadvantages of e-learning concluded that generally students who study online were involved in academic fraud cases as compared to conventional students who attend daily classrooms and therefore suggested some 
measures to overcome academic fraud. Khader, Mohamed Ramdan and Abdul Hafeez (2013) proposed a conceptual model to compensate deficiencies of e-learning based on Islamic principles. The researchers asserted that Islamic philosophy in education be applied to the tools and application in the online education platform to produce effective society member.

Generally, there is insufficient body of knowledge presented on the Islamic perspectives on guidelines for online learning. Hence, this study aims to contribute to the existing literature by presenting the Islamic perspectives in terms of the ethics of using the new media in education in general and especially during Covid19. Although sufficient research has been carried out into ethics of online learning, little is known about specific applications of the rules of do's and don'ts for users of new media in the Covid19 online learning situations. This study, therefore, offers to analyse and present ethics for using the new media in education especially in facing the challenges of learning during the unprecedented Covid19 phenomena.

\section{Methodology}

This concept paper analyses data extracted from referencing secondary sources such as academic journal articles, scholarly books and online newspaper articles to understand new media and current online distance learning situations taking place during Covid19 phenomena. In brief, qualitative data was elicited from several significant main themes and sub-category themes which made it possible to come up with interpretations towards presenting concepts of Islamic perspectives on ethics of using new media in education which are relevant for teachers and students. Essentially, the main themes and concepts relate to ethics which reflected conducts and value based on two categories which are mahmudah or good moral conduct and mazmumah or bad moral conduct (Roshinon, 2008).

In this paper, the main themes relate to the concepts of Do's (good moral conduct) and Don'ts (bad moral conduct). In Islam, moral conduct is very important to human beings with regards to Allah, human beings, environment and the universe itself (Mujaini, Asiah, Mohd Asri, 2002). Next, the subcategory themes pertain to moral value and conduct which could guide educators and learners to use the new media properly and positively (the Do's) which primarily reflected the concepts of learning ethics and use of ICT for learning and communication, balance between human and society (Khurshid, 1982), measurement of ethics and moral (Zawiyah et al., 2007), and also creating an ethical society. Whereas, the Don'ts (bad moral conduct) reflected concepts of misconduct which ought to be avoided during online learning processes, in addition to concepts of principles and guidelines of online learning based on the self-experiences of the researchers as educators during their Covid19 teaching situations.

Significantly, the aspects of ethics of using the new media are proposed by experienced educators who had teaching experiences in recognized public universities in Malaysia from the education, creative design and Islamic studies background. Some had teaching experiences for more than twenty years, while the younger ones from four to seven years of experiences. Currently, the syllabus in their respective universities required the instructors to conduct blended learning classrooms even before the Covid19 phenomena, which means that students learn via electronic and online platforms, as well as face-to-face classes. It is hoped that the ethics suggested in this study would fit the needs of current educators and students to go through the online learning processes positively.

\section{Result \& Discussion}

\subsection{Ethics for Using New Media: Islamic Perspectives}

Figure 1 presented the Conceptual Framework on ethics for using the new media in education. The next sections discuss the aspects reflected in the diagram. 


\section{Conceptual Framework}

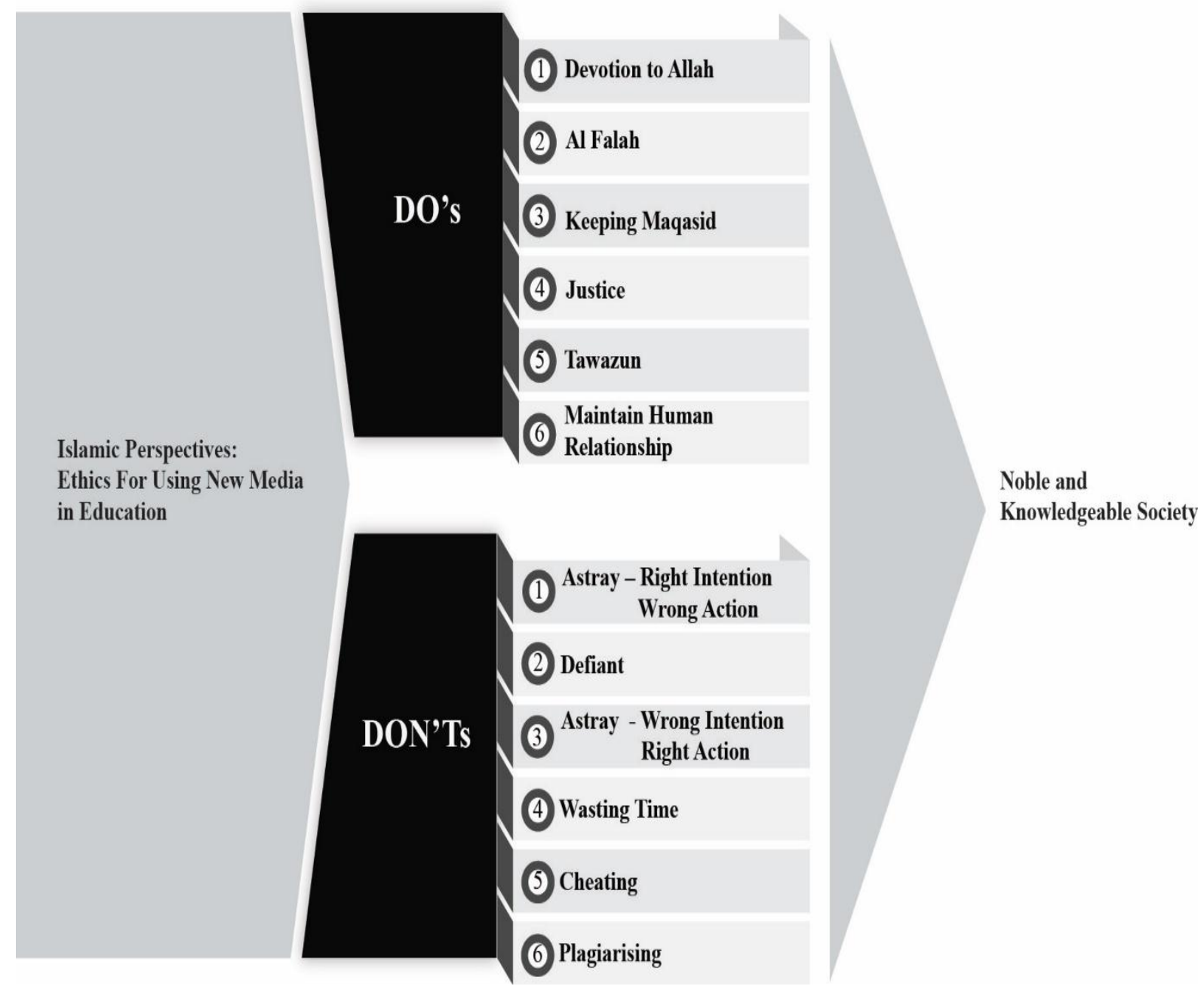

Figure 1. Education During Covid19: Ethics for Using New Media

Islam places great importance on ethics for the good of the ummah. Muslims are responsible to adhere to the ethics of using the new media according to Islamic teachings and values. This means that Muslims ought to be noble individuals advocating noble characteristics or ' $k h u l u q$ ' as described in the Quran: And that thou art indeed a noble character"(Al-Qalam 68:4). The use of new media technology has to adhere to Islamic principles in terms of doing acts of worship and as means of cultivating faith. This section discusses Figure 1 which shows the ethics for using the new media in education according to Islamic perspective comprising of ethics in terms of the Do's and the Don'ts.

\subsection{The Do's in Using New Media in Education}

\subsubsection{Devote to Doing the Right Intentions and Actions}

Zawiyah et al. (2007) stated that acts of devotion to Allah means that individuals must do things with the right intentions and the right actions. Therefore, in using the new media, individuals must bear good intentions when performing their tasks. Prophet Muhammad (Peace be upon him) said:

Every practice depends on its intention"(Hadith History of Bukhari and Muslim from Amir alMukminin Umar Al-Khattab) 
Individuals are deemed as doing acts of worship, if their intentions and actions are right. Eventually, good deeds become beneficial to others, and others would regard such person respectfully. Devotions to perform tasks with good intentions would then be rewarded by Allah. For example, the knowledge and information disseminated from teachers to students, students to students, or teachers and students to parents need to be genuine and truthful. Teachers and students need be honest and the learning process must benefit all creatures and also the environment. Interactions and actions must be respectful leading to the paths of Islam and adhere to Allah's commands to His servants. In fact, teachers must become good role models to their students as students tend to emulate positive noble actions or words used in the learning process reflected by their teacher role models online and offline.

During Covid19 situations, teachers and students could do good deeds by teaching and reminding each other about stopping the spreading of the Covid19 virus by wearing masks, practising cleanliness and maintaining good health practice such as washing hands 20 seconds regularly, disinfecting and cleaning homes and surrounding areas, and practising social distancing. Parents and teachers should also guide and motivate their students and children to use the new media positively and to avoid negative deeds during the challenging times.

\subsubsection{Achieve Happiness and Well-Being or Al-Falah}

Al-Falah is the success and well-being of human life which included physical well-being and peace which can be achieved through the balance of one's emotional and material needs (Nor Sahida and Sanep, 2013). Al-Falah would motivate and inspire each Muslim individual to put in every effort into his or her work (Seun, and Kalsom, 2015). Teachers and students are then motivated to do things the halal way to feel happy and satisfied with their success. The use of new media for teaching and learning, business, and communication must ensure that the deeds are done towards the path of $\mathrm{Al}$ Falah or achieving one's success, happiness and well-being in the world and the hereafter. Teachers and students need to spend time and share positive words to appreciate students' commitments to commit to online classes and appreciate honest students who had completed their assignments, tests and projects as best as they could and with integrity. Allah SWT said:

The believers must (eventually) win through, they who are during their prayer humbly submissive, who avoid vain talk. (al-Mu'minūn, 23:1-3)

According to Sayyid Qutb (2009), such instruction provided the qualities of believers who are definite to achieve Al-Falah such as all playfulness and foolishness in words, tasks, or matters. A believer's heart has its own preoccupations which steer it away from frivolity. Undeniably, the act of leaning and maintaining academic grades online are not easy feats during Covid19 and online distance learning contexts where students engage and learn in isolation learning spaces rather than being able to discuss face to face and collaborate with their peers when they do their assignments, projects and so on. By showing appreciation and compassion between teachers and students, Al-Falah could be felt by the individuals, and therefore the teaching and learning situations at home or in offices become peaceful and satisfying.

\subsubsection{Keeping Maqasid (Goals/ Purposes)}

Maqasid syariah can be explained as the commitments, values and intelligence established by Shari'ah Islamiyyah in the sanctioned judgments including their implications to guard human wellbeing (Zulkifli Mohamad Al-Bakri, 2019). Maqasid syariah also acts as the parameter and yardstick in many aspects for example civil rights, education, economic development, community governance including information communication and technology. Keeping maqasid syariah or purpose of syariah is a core point in a Muslim's life. Hence, the use of the digital media should not overlook this element. A person must not use digital media as a tool to attack an individual's personality, disgrace others, and make use of digital technology to make profit which is not allowed in Islam. Educators and students 
should not give false news that could make others become fearful or worried and add to the already worrisome situation with regards to the contagiousness and danger of the Covid19 infections. A person can discipline himself or herself to have good ethics to know whether his or her actions are moral or immoral when using the new media.

Furthermore, in keeping maqasid, school administrators could take the time of the online distance learning to do repairs and cleaning the learning compounds and uploading these positive and honourable deeds to the school's website to inform people that the schools are concerned with the well-being of the students and teachers in their learning institutions.

\subsubsection{Practice Justice in Receiving and Giving Information}

When using the new media, one should practice justice. An individual should filter the information first and put justice to the news whether it is true, genuine and does injustice to others especially when he or she is uploading or downloading any information. Justice here means that the information is not simply being changed for one's own benefits, and the information and resources are unbiased and without containing any biased personal interests. The act of practising justice adheres to Allah's commands:

O ye who believe! Be ye all steadfast in the cause of Allah, for the truth; and never let your hatred against a person induce you to not do justice. Be fair (to anyone) because fairness is closer to the taqwa. And be careful of Allah, surely Allah is well-acquainted with what you do. "(Al-Mā'idah 5: 8)

Apparently, Islam stresses on several qualities of communicators such as justice whereby a communicator ought to relay information without any regards to any party and communicate accurately with the regards to the problem (Muhammad Taufik Md Sharipp, 2018). Significantly, to uphold justice means that a person is able to have the awareness, knowledge and skill to grasp hold of his or her behaviour and ensure that he or she uses the information and knowledge in the new media for the common good of all. There are also positive instances where schools, teachers and students do justice if they hear any information about others who are facing problems during Covid19 lockdowns where families are directed to stay at home. All parties in the learning institutions must help out students and individuals who are badly affected where students' families and school staff family members lost their income and have no money to buy food and own ICT tools for online distance learning. The school community must work together to help these poor and unfortunate people to continue living comfortably and capable to learn in online distance learning sessions. Therefore, as responsible citizens, people should do justice towards those who are unfortunate and less fortunate to help them feel the love of Islamic principles and teachings.

\subsubsection{Practice Balance (Tawazun)}

All Islamic teachings are tawazun in order to avoid stress and chaos. Lukman Hakim et al. (2019) stated that the goal of tawazun in Islamic perspective of education is to create individuals who are virtuous, truthful, humble, disciplined, dynamic, and healthy in mind, spirit, body. All parties involved in the education process need to exercise balance in all aspects of life. Islam prohibits over-extremism. As mentioned in Quran:

"Seek instead, by means of what God has granted you, the good of the life to come, without forgetting your rightful share in this world." (Al-Qasas, 28:77).

Hence, Islam promotes the right balance in characteristic of the divine way of life (Syed Qutb, 2009). This principle is also significant to the use of a new media. Islam does not condone the act of being cyber-troopers or netizens who act with extremism when condemning others or saying negative things online. Nonetheless, Islam permits the use of new media technology as long as it does not violate any sharia restrictions. 
Therefore, new media users must be able to practice balance when they are online to avoid harm. Good ethics such as tawazun in using digital media are useful to control the behaviour of digital media users to ensure that users minimize and avoid disaster. Essentially, an individual must be exercise tazawun and be able to regard positive information and knowledge; and consequently, he or she should only viral positive issues or issues that could benefit the society positively in order to uphold a positive environment for young and adult users (Jamiah et al., 2016).

\subsubsection{Maintaining Human Relations with Others}

New media users need to encourage and engage in healthy and positive human relationship, and must not use the new media in ways which can set humans apart especially during the Covid19 situation. Being quarantined at home and exercising online studies and doing work from home are quite stressful and challenging for all. This is an unprecedented event whereby people become confined at home. Hence, it is important to stay positive and respect each other's rights and personal space to create positive environment at home. For example, society's right is an example of what should not be harmed in the name of freedom. All family members have their rights that must be respected. Every teacher and student has the right that must be respected by all the individuals in the unit. It would be good to maintain human relationship because the bonds within family members and even classroom relationships can fade when members in the unit are too preoccupied or obsessed with mobile phones online and offline.

Finally, the rights of a teacher, student, administrator, family member, and colleague must also be upheld and respected to foster excellent human relationship with others. Attention to time, space and learning materials must be given concern by the educators and students to enable them to cooperate and collaborate in the online digital learning process. The situation is not the same as in the relationships and time spent between teachers and students in real classrooms. In online learning and working situations from home, individuals have to juggle their time in completing household chores and sharing learning spaces with other family members in a confined household while engaging in learning activities during the day or even at night. Thus, everyone must keep their spirits up and show each other a little patience, empathy, and care to make online learning environment more bearable for each other. All in all, eventually, all individuals should work together to maintain a healthy relationship with others, as what Allah commanded all humans do, which is to secure a healthy relationship with humans and all other things on earth.

\subsection{The Don'ts in Using New Media in Education}

Table 1. Contingencies of Intentions and Actions

\begin{tabular}{|c|c|c|}
\hline & Right Action & Wrong Action \\
\hline Right Intention & Devotion & Astray \\
\hline Wrong Intention & Astray & Defiant \\
\hline \multicolumn{2}{|c|}{ Adapted from Zawiyah et al. (2007) } \\
\hline
\end{tabular}

\subsubsection{Going Astray by Having the Wrong Intention Although Doing the Right Action}

Referring to Table 1, Zawiyah et al. (2007) drew up some contingencies of intentions and actions to list divisions of actions of do's and don'ts. It stated that an individual is deemed of going astray from the right path when he or she kept the wrong intention even though he or she thought that he or she 
was doing something right. For example, when students and teachers use the new media in the learning process or even use it to spread Islamic information and teachings, it is considered as a praiseworthy deed. Nevertheless, this act would also become a sin, if the actual intention of the individual is wrong, such as trying too much to be seen as someone who is wise on the social media, but the individual is actually someone who is spreading misguided Islamic information to others.

\subsubsection{Being Defiant by Having the Wrong Intention and Doing the Wrong Action}

Next, as seen in Table 1, Zawiyah et al. (2007) stated that an individual is deemed as being defiant when he or she has the wrong intention and performing the wrong thing. Certain irresponsible people whether they are educators or students, use the media with wrong intention and action. Examples of such people are those who would sabotage others by posting false information, insulting, slandering, and altering information intentionally. Certainly, these acts are clearly sinful as the impacts would be injustice or hurtful and cruel to others.

Another example is that there are also incidents reported from abroad that due to excessive playing of computers, there were recorded deaths, injuries, and abusive cases. Therefore, these scenarios are the best examples with regards to the effects of ethical neglect. Moreover, users of the new media are exposed to various risks such as internet abuse, illicit social affairs, hacking and other negative practices. Individuals must also not insult and look down upon their peers and most importantly, during the mentally challenging time of Covid19 situations, they must avoid being cyber bullies, online gamblers, scammers, haters, playing sexually and violent oriented virtual games, and negative keyboard warriors when surfing online.

\subsubsection{Going Astray by Having the Right Intention but Doing the Wrong Action}

Finally, based on Table 1, being astray from the right path is also when one has a good intention but, it is carried out with the wrong action. Such actions do not mean that the actions are acceptable in the eyes of God and in Islam, as the actions are still considered as wrong doings and are considered as sins if the actions violate others. For example, an individual upload a true story on social sites as a lesson to the community; however, if the story ended up insulting or humiliating a person, then such an action is considered as wrong and astray from Islamic paths.

\subsubsection{Wasting Time on New Media Platforms}

In a Hadith by Prophet Muhammad as narrated by Abdullah bin Masoud, "A man shall be asked four things on the day of Judgment- concerning his life how he spend the time, about his youth, how he grew old, his wealth, how he got it and how he spent it, and finally what he did with his knowledge. A person who does not follow the ethics and integrity of Muslims would then spend his young age by wasting time on new media platforms. During the stay at home and learning through online distance learning platforms, students could end up wasting too much time on screen to do irresponsible activities. The young generation especially students should not do negative activities online such as spending too much time on social media to read up viral news, playing Tik-Tok, playing virtual games, insulting others, exchanging gossips, telling tales, and sharing inappropriate information, emotions, moods, and problems to virtual followers. Some students ended up ignoring families, friends and teachers and classroom work when they become obsessed with their virtual world activities.

There are also incidences of students who just register attendance to their online classes, and then switch to the mode of playing games, chatting and continue their resting and sleeping habits, and watching YouTube videos after they have signed their classroom attendance, for example by switching off their camera video and sound mode during the virtual classes using platforms such as Google Meet classrooms, Zoom meeting, and others. Students who are undisciplined with their time could become complacent and irresponsible in their academic sessions and become demotivated to learn. They may 
also become addicted to spending much time on screen doing wasteful activities rather than being responsible learners during online distance learning.

\subsubsection{Cheating in Online Tests, Exams, Assessments and Assignments}

As teaching and learning processes occur online, assessments such as tests, projects, presentations, examinations and others also may take place online during the period of Covid19. Thus, students can also become greedy and resort to cheating just to secure better grades.

Moreover, due to advanced technology of the websites as sources of knowledge, students could misuse and figure out various ways to cheat. It is unethical and a wrong and sinful thing to do when a student resort to cheating during online assessments. There are many possible unethical ways such as opening a tab to look up answers, sending questions and sharing answers with their friends, taking screenshots of the quiz questions, writing down "cheats" on their hands or papers, checking definitions and spelling by right-clicking on words, or even asking someone else at home to answer the online tests for them (Sowash, 2019).

Ultimately, teachers and students should bear mind that Islam prohibits cheating in examinations no matter on what grounds because the Prophet (peace and blessings of Allah upon him) said that "The one who cheats (or deceives) us is not one of us" as narrated by Muslim (101). Thus, the sinners need to repent and not cheat and deceive again.

\subsubsection{Plagiarising Other People's Work}

Plagiarising is another unethical and wrongful act that students need to refrain from during online learning and evaluation situations to get better grades. Students must not cut and paste from the internet without proper citations. In addition, students must not share work with their friends online. Basically, the greed to plagiarize other persons' work is more when doing assignments or tests online because the sources are readily available out there in the digital space for anyone to use and it provides a very easy and quick solution to solve problems. Hence, it is a sin to be tempted in this wrongdoing and the sinner needs to repent and resolute not to cheat and deceive again. Busikova and Melicherikova (2013) recommended learning institutions highly increase student-teacher interaction in forums through multimedia tools and to establish a solid academic plagiarism checker technology.

\section{Contribution of the Study}

Users of the new media should be concern with ethics and the do's and don'ts, especially when they are forced to learn online during Covid19. Moreover, individuals also need to embrace knowledge and ethics so that they become noble new media users. The ethics proposed in this study could serve as guidelines to contemporary new media users engaging in digital learning. Essentially, individuals must embalm positive elements when using the new media in the education environment. Elements such as establishing good relationship and valuing others, showing empathy and benevolence, asking respectfully, being just and honest and other positive ethics should be learned and practised by new media users in our modern society (Ezad Azraai et. al., 2004).

Therefore, parents and educators must ensure that they are transparent and open minded with regards to the use of new media and advanced digital technology before they allow the young ones to have much freedom to use new media gadgets and internet technology. Without proper monitoring and guidance, youngsters and even adults may get addicted and obsessed with such technologies especially during the Covid19 situations, where people are restrained to stay safe at their homes. 


\section{Conclusion}

To conclude, knowledgeable individuals must use the new media ethically. In line with the AlQuran and Al-Sunnah, the value of Iqra or knowledge should be highlighted among current new media users as they use the online platforms to connect with one another during the Covid19 situations. It is important to note that individuals who do not make knowledge and science as the main elements in their lives could end up being scammed and humiliated easily by other people.

It is hoped that this paper serve to help contemporary new media users to use the technologies responsibly. Parents, caretakers, students and teachers must make the best effort to grasp the many transformations in the education experiences due to Covid19. Eventually, all intentions and actions to do things must be guided by religion and good moral values to ensure beneficial outcomes from using modern technology (S. Salahudin et. al., 2006).

\section{Acknowledgement}

The project was supported by the Ministry of Education, Malaysia under the Fundamental Research Grant Scheme (Project No. FRGS/1/2018/SSI03/UITM/02/4). We would like to thank the Ministry of Higher Education Malaysia, Research Management Institute Universiti Teknologi MARA (UiTM) and UiTM Melaka campus for the financial support, facilities and co-operation.

\section{References}

Aziz Rehman Saifee et al. (2012). The Role of Mass Media and Information Technology in Islamic Education. European Journals of Social Sciences, 32(3), 380-390.

Busikova, A., \& Melicherikova, Z. (2013). Ethics in E-Learning. IADIS International Conference eLearning.

Ezad Ezraai et al. (2004). Pengajian Islam. Shah Alam: Fajar Bakti.

Jamiah et al. (2016). Penggunaan dan Implikasi Media Sosial Terhadap Remaj GenerasiZ. Proceedings from International Conference on Social and Economic Development.

Juritah Misman, Muhammad Taufik Md Sharipp, S. Salahudin Suyurno, and Sumayyah Shaidin. (2018). Islamic Perspectives Using New Media in Education. International Journal of Academic Research in Progressive Education and Development, 17-21.

Khader Musbah, Mohamed Ramadan Saady \& Abdul Hafeez. (2013). Comprehensive ELearning System Based on Islamic Principles. $5^{\text {th }}$ International Conference on Informationand Technology for the Muslim World.

Khurshid Ahmad. (1982). Islam and Its Meaning and Message. Islamic Foundation. Dewan Pustaka Islam: Kuala Lumpur.

Lengel, L. (2004). Computer Mediated Communication: Social Interaction and the Internet. London: Sage Publication.

Lukman Hakin et al. (2019). Peran Guru Pendidikan Agama Islam dalam Menumbuhkembangkan Sikap Tawazun di SMP Al-Kautsar Banyuwangi. Vicratina: Jurnal Pendidikan Islam, 4(4), 181187. 
Muhammad Taufik MdSharipp. (2018). Hubungan Manāhi Rabbanīyyahdalam Dakwahdengan Kredibiliti Komunikator Islam Media Baharu. Master Thesis for Academy of Contemporary Islamic Studies Universiti Teknologi MARA.

Mujaini Tamirin, Asiah Ali and Mohd Asri Abdullah. (2002). Insan dan Agama. Pusat Pendidikan Islam. Universiti Teknologi Mara Malaysia.

Nor Sahida Mohamad., \& Sanep Ahmad. (2013). Development from Islamic Perspective: An Interim Analysis. Proceeding PERKEM, 8, 1, p. $355-370$.

Rosihon Anwar. (2008). Akidah Akhlak. Pustaka Setia: Bandung. Indonesia.

S. Salahudin Suyurno dan Mohd Yadman Sarwan. (2003). Islam dan Internet: Keperluan Kepada Piawaian Etika Kepenggunaan Internet di Malaysia Kolokium Ilmu-Ilmu Islam. Anjuran CITU UiTM Shah Alam, Hotel UiTM.

S. Salahudin Suyurno et.al. (2006). Sains dan ICT: Peranan \& Cabaran Menurut Perspektif Islam. Shah Alam: UPENA.

Sayyid Qutb. (2009). In the Shade of the Quran. (Factors of Social Muslim prenuers. Pertanika Journal: Social Sciences and Humanities, 23(S),17-32.

Sipalan, J. (2020). Malaysia Closes Borders, Schools, and Businesses as Virus Tally Climbs. Reuters. 16 March 2020. Accessed on 12 April 2020. reuters.com

Sowash, J. (2019). 5 Ways to Prevent Cheating on Your Google Form Quiz. Retrieved from https://www.techlearning.com on 10 April 2020.

Toprak, E. (2010). Ethics in E-learning. The Turkish Online Journal of Education Technology, 9.

Yahe Pallavicini, S. Y. (2016). Interfaith Education: An Islamic Perspective. International Review of Education, 62.

Zawiyah Mohammad Yusof et al. (2007). Teknologi Maklumat dan Komunikasi: Etika, Undangundangdan Sosial. Shah Alam: McGraw-Hill. Edisi Ke-2.

Zetty Nurzuliana Rashed \& Ab.Halim Tamuri. (2015). Kepentingan Integrasi Ilmu Naqli dan Ilmu Aqlidalam Pengajaran Pendidikan Islam, E-Jurnal Pendidikan, 2(1), 5-14.

Zulkefli Aini \& S. Salahudin Suyurno. (2012). Asas Komunikasi Dakwah. Bandar Seri Putra: KUIS Zulkifli Mohamad Al-Bakri (2019) Irsyad Usul Al-Fiqh Series 33: Introduction to Maqasid AlSyari'ah. https://muftiwp.gov.my/en/artikel/irsyad-usul-fiqh/3099-irsyad-usul-alfiqh33introduction-to-maqasid-al-syariah

\section{AUTHORS BIODATA}

Juritah Misman is a senior lecturer at APB, UiTM Melaka. She has a Bac.Ed.Hons. (TESL) UPM and M.Ed. (TESL) UTM. She had a national grant and had published her works in UiTM monograph, journal articles and conference proceedings. Her area of research is language skills, education and communication skills. She is ever grateful to lecturers and friends of TESL UPM, UTM and UiTM Education Faculty and APB UiTM for their knowledge, friendship and support.

Muhammad Taufik Md Sharipp is a lecturer at ACIS UiTM Melaka. He is a candidate for a doctoral degree in Contemporary Islamic Studies, Universiti Teknologi MARA (Islamic Communication). He holds a Bachelor degree in Sunnah Studies with Information Management, Universiti Sains Islam Malaysia (USIM) and a Master degree in Contemporary Islamic Studies (Islamic Communication). He is a takmir teacher with the Malacca Islamic Religious Department and also active in the field of Islamic communication studies. 
S. Salahudin Suyurno is an associate Professor at the Academy of Contemporary Islamic Studies (ACIS) UiTM Melaka, Alor Gajah. He obtained his first degree in Islamic Revelation and Heritage (IIUM), second degree in Political Science (IIUM), Masters in Islamic Information Management (Msc.) Information Management, UiTM) and $\mathrm{PhD}$ in Islamic Communication and Religious Psychology (UM). He is now the Head Centre Studies of ACIS UiTM Melaka.

Nik Narimah Nik Abdullah is a senior lecturer at FSSR, UiTM Melaka. She has a Bac. Of Art \& Design (Graphic Design) UiTM, MA of Art \& Design (Visual Communication) and PhD candidate (Fac of Edu, UKM). She had published her artworks in local exhibition, join a few innovation competitions, publish journal articles, conference proceedings and trainer for graphic design software. She is ever grateful to lecturers and friends of FSSR UiTM, and UKM Education Faculty for their knowledge, friendship and support.

Chairozila Mohd Shamsudin is a senior lecturer at Pusat Pengajian Citra, UKM Selangor. She has a Bac.Ed.Hons. (TESL) UPM and Masters and PhD UKM. Her field of research is on language, technology and writing. 